\title{
ENGINEERING LEADERSHIP IN POSITIVE SPACE
}

\author{
Peter E. Weiss, Lesley Mak, Susan McCahan, and Jason Bazylak \\ University of Toronto \\ weissp@ecf.utoronto.ca lmak@ecf.utoronto.ca mccahan@mie.utoronto.ca bazylak@mie.utoronto.ca
}

\begin{abstract}
Two years ago, a satirical column in the Engineering undergraduate comic newspaper elicited complaints and the accusation of homophobia from the university community. Engineering students, faculty and staff responded with several initiatives to counteract being stereotyped as homophobic. The Lady Godiva Bnad (sic), which had always marched in the Toronto Gay Pride Parade, actually built a float and set off the cannon, winning the (perhaps only ever) Shock and Awe Award. Faculty members, staff and students formed an Engineering Positive Space committee and, with the student group, LGBTQase (Lesbian, Gay, Bisexual, Trans, Queer and Allies in Science and Engineering), developed a poster that raised awareness of the diverse sexuality of engineering students as well as an Engineering Positive Space badge with a unique "engineering" variation of the Positive Space rainbow triangle.
\end{abstract}

Keywords: Positive Space: LGBTQ: Inclusivity:

\section{INTRODUCTION}

In the last two years, students, staff and faculty members in Applied Science and Engineering at the University of Toronto have established themselves as campus leaders in promoting inclusivity and the discussion of issues related to the Lesbian, Gay, Bisexual, Transsexual and Queer (LGBTQ) communities. Although the Faculty already had a student group, LGTBQ Allies in Science and Engineering (LGTBQase), the formation of an Engineering Positive Space committee allowed staff and faculty to join with students in creating sustained initiatives to promote awareness. In this paper, we want to share our experiences and encourage the development of similar groups in other Engineering schools.

Over the last 100 years, lesbian and gay identity, as well as the identity and understanding of other gender diversities, have undergone dramatic shifts [1-4]. After the 1960s many countries repealed laws which criminalized sexual acts between consenting adults of the same sex. However, since the $19^{\text {th }}$ century and the coining of the term "homosexuality," a "medicalization" of the phenomenon, as Michel Foucault put it, same sex attraction was also considered a problem that could be subject to medical treatment and even "cured." Thus, even when decriminalized, many lesbians and gay men were extremely reticent rather than open about their lives [1].

Moreover, in the last century, cultural representations of lesbian, gay or queer humans have not contributed to an atmosphere of positive self-affirmation. These have, often in heavily coded fashion, characterized members of the LGBTQ community as comic, odd or otherwise on the fringes of "normal" ways of life. It was not until after the AIDS crisis, which began toward the end of the $20^{\text {th }}$ century, that the general public became aware of the sexual diversity of figures, such as Rock Hudson, who was, himself, iconic of so-called "straight" gender behavior [4-5]. However, as Brian Pronger points out [6], those negotiating diverse sexual identities in such strongholds of conventional gender behavior as athletics still faced daunting challenges. They were, in Derek Jarman's words [7] attempting to define themselves "in a world which has never talked about us or even let us talk about ourselves.” (Quote from page 29.)

Even now, despite increasing "normalization" of same sex relations through conventional institutions of family, marriage and the raising of children, NBA player Jason Collins' public admission that he was gay made front page news [8-9]. Notwithstanding other famous athletes, particularly women, who have come out in the past, public figures, including other professional athletes and the President of the United States, were quick to praise Collins and commend him on his "courage," a recognition that it remains difficult for some people to be open about unconventional aspects of their identities. Collins begins his article, in the May 6, 2013 edition of Sports Illustrated [10], "I didn't set out to be the first openly gay athlete playing in a major American team sport. But since I am, I'm happy to start the conversation.”

"Conversation" is a good word. Positive Space is a way of opening "conversations" both directly in the meetings we hold and indirectly in the initiatives that we have been part of: a poster campaign, an Engineering Positive Space patch, and organizing a Pink Shirt Day event. 


\section{POSITIVE SPACE AT U OF T}

Positive Space began at the University of Toronto in 1995. Students, faculty and staff came together to talk about issues around sexual diversity and identified a need to engage members across the institution in a conversation about the challenges of LGTBQ community. Ideas around a sticker and poster campaign as well as education and programming emerged from this group and the Positive Space Campaign was developed to break through the silence and stigma that was attached to those who identified as queer and their allies [11]. Awareness of Positive Space spread throughout the university. Looking at the institution as a whole, $\mathrm{U}$ of $\mathrm{T}$ was becoming a more inclusive place where heteronormative assumptions were questioned, policies around equity and diversity became stronger and the Positive Space logo, an inverted rainbow triangle, was popping up everywhere on doorways, windows and signage.

In the Faculty of Applied Science and Engineering it is difficult to find information about the impact of the Positive Space campaign in its early days of the late 1990s to early 2000s. Unfortunately, though, there is a general sense that due to the large male population (historically approximately $70 \%$ or more) in the Faculty and sexist and homophobic attitudes embedded in traditions like cheers, variety night sketches, and student publications, the environment as a whole was not very inclusive to the LGTBQ community and in some circumstances, could be intimidating and unwelcoming. This would soon change.

\section{LGTBQ STUDENTS UNITE}

As Positive Space was an institutional level campaign, students at $\mathrm{U}$ of $\mathrm{T}$ created LGBTout specifically for their peers and allies. Smaller chapters opened up across the university in colleges, departments and faculties and in 2003 engineering students created the LGBTout Engineering Chapter. Graduate and undergraduate queer students and their allies created a presence in the faculty to promote positive space and give students a voice. Through their efforts, the Chapter was able to organize an annual Wine and Cheese event that would bring out 100+ LGTBQ students, faculty, alumni, staff and their allies to socialize and celebrate [12].

Activity within The Chapter subsided after 5-6 years as its founding members graduated, but it established traditions like the Pride Parade float and Village Pub Crawl, which grew out of a previous, more heteronormative tradition. It took place during the Engineering Society run Godiva Week, a week of spiritpromoting events during the first full week of classes in January as a parallel to Orientation Week in September. During Godiva Week, there was a pub crawl during which students would visit bars and clubs that were mostly frequented by the heterosexual population of Toronto. Students active in promoting LGBTQ awareness decided to integrate inclusive programming into Godiva Week by changing the venues for the pub crawl, choosing establishments in the core of the Church Wellesley Village (known as the Gay Village) instead. The feedback and participation was extremely positive as students saw that they could participate in their much-loved pub crawl in a different environment and still have a good time [13]. Students who may have felt intimidated by entering a gay bar or the Village itself learned they could enjoy themselves with their fellow engineers as well as Village community members, demystifying the LGTBQ community and opening minds.

In the fall of 2011, a few engineering students gathered to form LGTBQ Allies in Science and Engineering (LGTBQase) to renew the representation of those who identified as LGTBQ and their allies. The group started out small with around 15 active members participating in events like dodge ball and movie nights but eventually developed training and leadership workshops to educate students on sexual diversity and acceptance. An important accomplishment for LGTBQase was participation in Orientation 2012. They provided orientation leader training on LGTBQ issues and inclusiveness and were also invited to speak at the opening presentation for F!rosh Week, where they were able to demonstrate to 900 incoming first year students that $U$ of $T$ Engineering was welcoming and inclusive to all students, regardless of their sexual orientation. LGTBQase's growth and influence only increased as non-engineering students joined their ranks and they currently have a membership of 300 people [14].

\section{ENGINEERING STUDENTS SHOW THEIR PRIDE}

In 2004, members of the Chapter joined the central U of $\mathrm{T}$ contingent that marched annually in Toronto's Pride Parade. Students integrated core traditions from the Faculty into their appearance by dyeing themselves purple, bringing the Lady Godiva Memorial Band to play loudly, wearing their engineering coveralls and hardhats and bringing along the Cannon Guard to fire the Cannon, which is the faculty's mascot. They merged deeply established engineering traditions with those of Pride as some wore rainbow flags, and some marched dressed in drag [13].

The engineering student participation in Pride was so popular that that they were invited to return and now marching in the parade seems to have become as much an annual tradition for engineering students as the Gay Village Pub Crawl. What started as a handful of students 
with instruments and flags tagging along with the $\mathrm{U}$ of $\mathrm{T}$ contingent eventually evolved into a full-blown engineering Pride Float built from scratch by students. Appreciation by Pride Toronto was also given to the students and over the years they have accumulated several Pride Parade awards such as the "Special Judges' Award for the Biggest Bang" in 2007 and the "Special Judges' Award for Shock and Awe” in 2011.

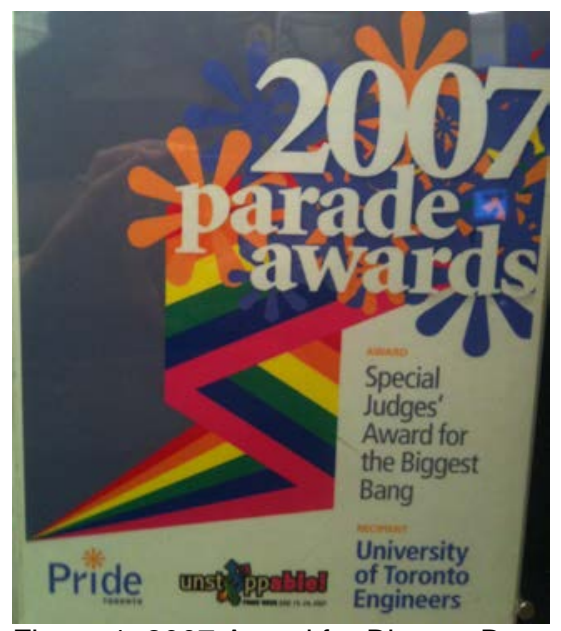

Figure 1: 2007 Award for Biggest Bang

\section{CONTROVERSY AND HOMOPHOBIA}

In October 2010, The Toike Oike, the engineering students' humour and satire newspaper published an issue that had an inflammatory editorial and fake ads that were broadly offensive and led to complaints of misogyny and homophobia from the Status of Women Office, the Faculty of Social Work and the Sexual and Gender Diversity office. The Faculty and the Engineering Society issued an apology and put the Toike under review but also looked into ways this incident could be used to bring the stakeholders together to talk about inclusiveness and community standards. A referendum was held to ask the students if they still wanted levy money to go to the publication and they responded positively; so the Engineering Society put a review process into place to avoid future incidents like this. The Faculty also developed a stronger relationship with the Editor of the Toike so a healthy ongoing discussion could be had about the goals and content of the publication.

\section{ENGINEERING POSITIVE SPACE COMMITTEE}

As members of the faculty and staff responded to the Toike Oike issue it became clear that the Faculty needed to increase its efforts to promote discussion and programming around LGTBQ issues and sexual diversity.
Conversations were initiated informally across the Faculty about the varying levels of acceptance and openness felt amongst those identifying as LGTBQ as well as their allies in regards to sexual identity. Some queer staff and faculty started honestly telling others that they never mentioned a same-sex partner or their personal life because they didn't believe they would be supported and understood [15]. Others who had been as out and open about their sexual identity as their heterosexual peers also were able to share their stories of acceptance and positive experiences. While a formal Community Issues and Gender Affairs standing committee was struck with membership and guidelines, LGTBQ community members and their allies like Dean Cristina Amon felt that a more informal, grassroots group needed to be pulled together in order to further nurture and grow the Positive Space movement in the faculty [15].

In winter 2011 a group of LGTBQ staff, faculty and allies held their first Engineering Positive Space (EPS) meeting. An open and engaging discussion on how to introduce training and education on homophobic language and unwelcoming traditions brought forth many ideas and proposals. The main outcomes of that meeting were the decisions to open up the group to student membership such as members from LGTBQase and that the group's focus would be to encourage "the spirit of equality and celebrate diversity" [16]

EPS picked up momentum once students joined with their voice, energy and experience. One of the first projects was to work with LGTBQase to devise a poster campaign that would be eye-catching, positive and educational. The "My hardhat isn't gay but I might be" poster that was launched in January 2012 was an immediate success, garnering attention across the institution for its eye-catching design and effective message (See Figure 2, below). This poster campaign represented the efficacy and relevancy of EPS and helped show the greater $\mathrm{U}$ of $\mathrm{T}$ community that Engineering could make significant contributions to the campaign for inclusiveness and sexual diversity.

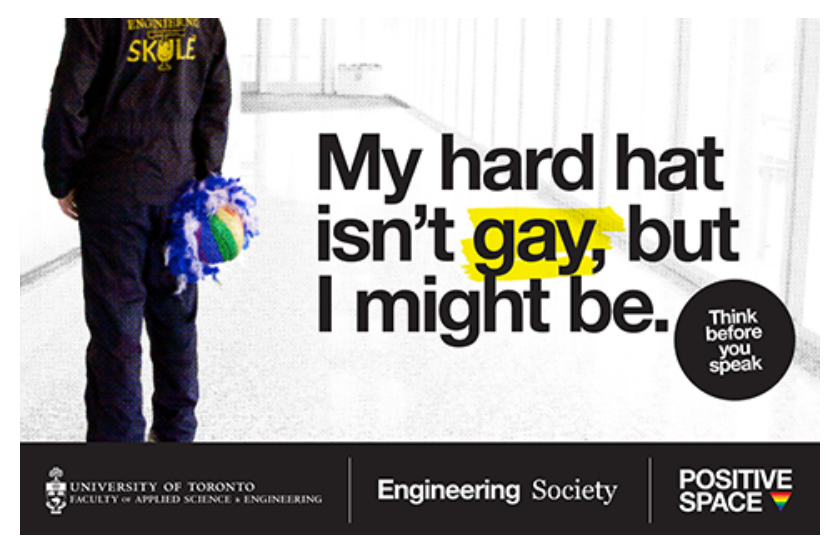

Figure 2: Engineering Positive Space poster 
The next major project was to create an Engineering Positive Space patch for students to sew onto their engineering coveralls and jackets (see Figure 3). It was agreed that training was necessary to accompany the distribution of the patches, since they would be worn by people and not just displayed on walls like the posters were. Since the patches were ready for distribution in Spring 2012, the timing was good for LGTBQase to put together an engaging and dynamic presentation to present to orientation leaders and student club leaders in their various summer training workshops. The training emphasized inclusive language and challenged heteronormative assumptions. Wearing the patch itself was completely voluntary but the focus of the training and campaign was to make sure the students who chose to wear it understood the responsibilities that came with brandishing the EPS insignia.

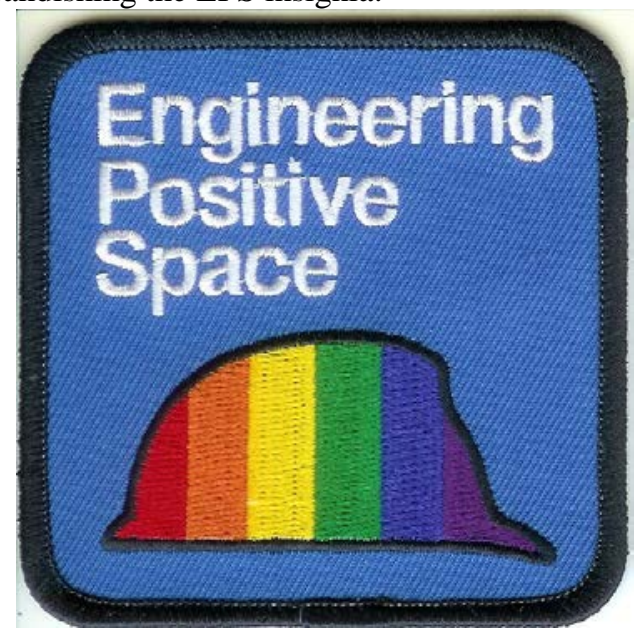

Figure 3: Engineering Positive Space badge

After creating two strong pieces focused on branding and visual identity, EPS decided to expand Faculty participation in awareness campaigns that were recognized across the world. Purple shirts with the rainbow hard hat logo from the patches were made for Anti-Homophobia Day on October 20th. For Pink T-shirt Day on February 26th, a lunchtime event was organized where students, staff and faculty were encouraged to wear pink t-shirts to school and come to the cafeteria to take pictures with their anti-bullying messages. The Cannon Guard also came dressed in pink t-shirts instead of their traditional black clothing to show their support. Participants wrote touching and thoughtful messages of support, hope and joy to show their peers, as well as the greater institution, that Engineering was a diverse and welcoming place.

\section{LESSONS LEARNED AND GOOD PRACTICES}

The evolution of Positive Space at $\mathrm{U}$ of $\mathrm{T}$ Engineering was due to a multi-pronged approach that engaged stakeholders at all levels at U of T Engineering. Students, staff and faculty were encouraged to form groups and committees that had freedom and independence while receiving vocal support from the Faculty. Funding from the Vice Dean Undergrad and various departments throughout the Faculty gave legitimacy to projects like the EPS patch and the Chapter's Wine and Cheese events. Promotional campaigns like the "My hardhat isn't gay, but I might be" poster showed students, staff and faculty across the university that Engineering was committed to Positive Space, encouraging people to join the EPS committee and attend its events and the EPS patch training helped students develop a better understanding of what it means to be an ally.

Students initiated very public and attention-getting projects like participation in the Pride Parade that showed the institution and the city of Toronto that Engineering was proud of its LGTBQ peers and allies. Events and promotions like these were often given coverage by the Faculty and university newsletters. Controversies like the Toike issue were handled with official apologies and retractions but also initiated discussions with students on what goals they had for their humour newspaper and what type of environment they wanted to foster for all members of their community.

It is important to note that students who were engaged and influenced by the Faculty and their peers' efforts to provide a Positive Space subsequently became alumni who felt a sense of pride about their Alma Mater. These alumni would share their stories about $\mathrm{U}$ of $\mathrm{T}$ Engineering's progressive approach to nurturing global citizens who had an understanding of diversity and the ability to understand issues from various perspectives [12]. While there will continue to be challenges and struggles in the evolution of equality, promotion of sexual diversity and growth of Positive Space, $\mathrm{U}$ of $\mathrm{T}$ Engineering's approach will be to focus on engaging and positive institution-supported, community developed programming where everyone can feel safe and welcome to participate in the discussion, propose a program and join in on the celebrations

\section{Acknowledgements}

The authors of this paper would like to acknowledge the members of Engineering Positive Space for their thoughts and contributions to this paper. We would also like to acknowledge and thank St. George Positive Space, Sara Jane Finlay and Sara Marni-Hubbard for their 
support and workshops as well as the Sexual and Gender Diversity Office (SGDO) former officer, Jude Tate (who helped us set up Engineering Positive Space) and current officer Allison Burgess and Program Coordinator, Scott Clarke and, for their support of our activities, especially the workshops prepared by LGBTQase in relation to the EPS badge.

\section{References}

[1] Byrne R.S. Fone, Ed., The Columbia Anthology of Gay Literature. NY: Columbia University Press, 1998. 10 pp. \{ISBN: 0-965-68417-2\}

[2] Martin Duberman, Ed., Queer Representations: Reading Lives, Reading Cultures. New York, N.Y.: New York University Press, 383 pp. \{ISBN: 0-8147-1883-3\}

[3] Martin Duberman, Martha Vicinus, and George Chauncey, Jr., Eds., Hidden from History: Reclaiming the Gay \& Lesbian Past. New York, N.Y: Meridian, 1989. 575 pp. \{ISBN: 0-452-01067-5\}

[4] Vito Russo, The Celluloid Closet. [Documentary film] US, 1996.

[5] Mark Rappaport, Rock Hudson’s Home Movies. [Documentary film] US, 1992.

[6] Brian Pronger, The Arena of Masculinity. Toronto, On: University of Toronto Press, 1992. 297 pp. \{ISBN: 0-80207705-6\}

[7] Derek Jarman, At Your Own Risk: A Saint's Testament. Woodstock, N.Y.: Overlook Press, 1993. 151 pp. \{ISBN: 087951-538-4\}
[8] Mary Clare Jalonick and Josh Lederman, “Jason Collins' coming out as gay gets praise from Obama, Bill Clinton,” Toronto Star. [Online] Available: http://www.thestar.com/news/world/2013/04/29/jason_colli ns_coming_out_as_gay_gets_praise_from_obama_bill_clint on.html

[9] “NBA player Jason Collins announces he's gay,” CBC News. [Online] Available: http://www.cbc.ca/sports/basketball/nba/story/2013/04/29/sp -nba-jason-collins-sports-illustrated-gay-rights.html

[10] Jason Collins and Franz Lidz, "Why NBA center Jason Collins is coming out now,” Sports Illustrated.com [Online] Available as of April 29, 2013: http://sportsillustrated.cnn.com/magazine/news/20130429/ja son-collins-gay-nba-player/

[11] Office of Student Life, "Introduction to the Positive Space Campaign.” [Online] Available as of March 1, 2011: http://www.positivespace.utoronto.ca/introduction.htm

[12] L. Ng, personal correspondence, April 2013

[13] C. Roscoe, personal correspondence, April 262013

[14] J. Tobia, personal correspondence, May 2013

[15] L. Simpson-Camilleri, personal correspondence, April 2013

[16] Meeting Minutes, November 4, 2011, Engineering Positive Space, University of Toronto, unpublished. 